\title{
Economic Viability in Eucalyptus spp. Clonal Plantation for Production of Pulp
}

\author{
Janderson de Oliveira Silva ${ }^{1}$ (D) 0000-0001-8089-0936 \\ Fábio Gomes Monteiro 2 (D) 0000-0003-4387-9759 \\ Leidy Alves dos Santos ${ }^{3}$ (D) 0000-0001-9613-1424 \\ Jonas Elias Castro da Rocha ${ }^{4}$ (1) 0000-0002-0255-087X \\ Gabriel Magalhães Miranda² (1) 0000-0001-8536-6658
}

\begin{abstract}
Economic analysis assists the administration of forest projects (mainly long-term ones) in providing solidity to the investment. This study aimed to analyze the economic viability of an eucalyptus plantation used for pulp production in the mesoregion of Southern Pará, Brazil. Financial analysis was performed using the following methods: net present value (NPV), equivalent annual value (EAV), soil expectation value (SEV), internal rate of return (IRR), and benefit-cost ratio (BCR). Additionally, sensitivity analysis was conducted to identify the cost and revenue values that would represent the interface regarding the viability of the project. To this end, a cash flow was created for different scenarios of cost and revenue. The economic indicators demonstrated that the investment, as proposed in the marketing of standing timber, proved to be economically viable. Sensitivity based on the updated net revenue, despite fluctuations, made the project profitable.
\end{abstract}

Keywords: cash flow, forest economics, financial sensitivity analysis.

\section{INTRODUCTION AND OBJECTIVES}

In Brazil, due to exploitation of nature, forestry has been conducted primarily aiming at direct benefits for the manufacturing of goods. In the regional economy of Pará, timber production presents increasing importance, generating jobs and income to the local population. Brazil has one of the largest areas of planted forests worldwide, most of which are reforested using species of the genus Eucalyptus (Carvalho et al., 2005).

Data from 2017 shows 7.84 million hectares of planted trees in Brazil in 2016, with a growth of 0.5\% over the previous year. Eucalyptus plantations occupy 5.7 million hectares, accounting for $72 \%$ of this area, and are located mainly in the states of Minas Gerais (24\%), São Paulo (17\%), and Mato Grosso do Sul (15\%). This sector includes a range of companies, investors, and entrepreneurs that work from the supply of specific inputs and machinery for forestry, to the processing of wood into intermediate and final goods (Ibá, 2015). Of the nearly 7.8 million hectares planted in 2016 - representing less than $1 \%$ of the national territory, $34 \%$ belong to companies in the pulp and paper industry, $29 \%$ are independent operators and participants in outgrower schemes (small and medium-sized independent producers) who invest in forest plantations for the commercialization of roundwood, and $14 \%$ are allocated in the charcoal-fired steel sector (Ibá, 2017).

Planted forests account for approximately $92 \%$ of all wood produced for industrial purposes in Brazil, contributing significantly to the Brazilian Gross Domestic Product (GDP). This is still a growing sector despite the current economic crisis undergone by the country and

\footnotetext{
${ }^{1}$ Traterra Terraplanagem e Reflorestamento Ltda., Parauapebas, PA, Brasil

${ }^{2}$ Universidade Estadual do Centro-Oeste (UNICENTRO), Irati, PR, Brasil

${ }^{3}$ Universidade Federal Rural da Amazônia (UFRA), Belém, PA, Brasil

${ }^{4}$ Universidade Federal Rural da Amazônia (UFRA), Paragominas, PA, Brasil
} 
represented $1.2 \%$ of the total GDP and $6.0 \%$ of the industrial GDP in 2015 (Ibá, 2016).

Faced with such a scenario, it is the responsibility of producers not only to assess the silvicultural aspects of forest plantation planning, but also the aspects of commercialization of production, involvement of social forces, economic policies, dependence on climatic conditions, determination of income, direct benefits, capital turnover, liquidity and equity, extension of planted area, and comparison with other rural activities, seeking productivity and quality simultaneously. Once the planning is done, the rural producer/entrepreneur must systematize it into a management plan that should contain an economic feasibility study of the enterprise (Sant'Anna \& Leonel, 2009).

Sensitivity analysis shows the extent to which a change in one or more items of the cash flow maintains the outcome of project viability unchanged. Ideally, this analysis should be able to evaluate the behavior of prices and products, at least in the last five years, so that the amplitude of variation could be determined in this period (Santana, 2005). In this context, the present study aimed to assess the economic feasibility of a Eucalyptus sp. plantation used for pulp production through economic indicators and perform a sensitivity analysis of the results of this enterprise located in the municipality of Ipixuna do Pará, in the state of Pará, Brazil.

\section{MATERIALS AND METHODS}

\subsection{Characterization of the study area}

Eucalyptus clones adapted to the climate of the northern and northeastern regions of Brazil were used in this study. To this end, a forest project of eucalyptus with $3.5 \times 2.0 \mathrm{~m}$ spacing, 7 -year rotation, and single final pruning was considered. The production was marketed at an estimated price of $R \$ 65.00 / \mathrm{m}^{3}$, according to the value negotiated by the company, considering the standing timber and the production used for pulp. Data to determine the technical-economic characteristics of the project were obtained through a questionnaire and field monitoring.

\subsection{Location of the study area}

Climate in the municipality of Ipixuna do Pará is Aw according to the Köppen-Geiger classification. The region presents an average annual temperature of $26.3{ }^{\circ} \mathrm{C}$ and an average annual rainfall of 2,205 mm (Climate-Data.org, 2016). Fazenda São Pedro is located near the boundary between the municipalities of Ipixuna do Pará and Paragominas. The farm has an area of approximately 24,000 hectares, with 21,000 hectares of native forest and 3,000 hectares of planted eucalyptus trees. The stands used for the database and the farmhouse are located $65 \mathrm{~km}$ away from the municipality of Ipixuna do Pará (Figure 1).

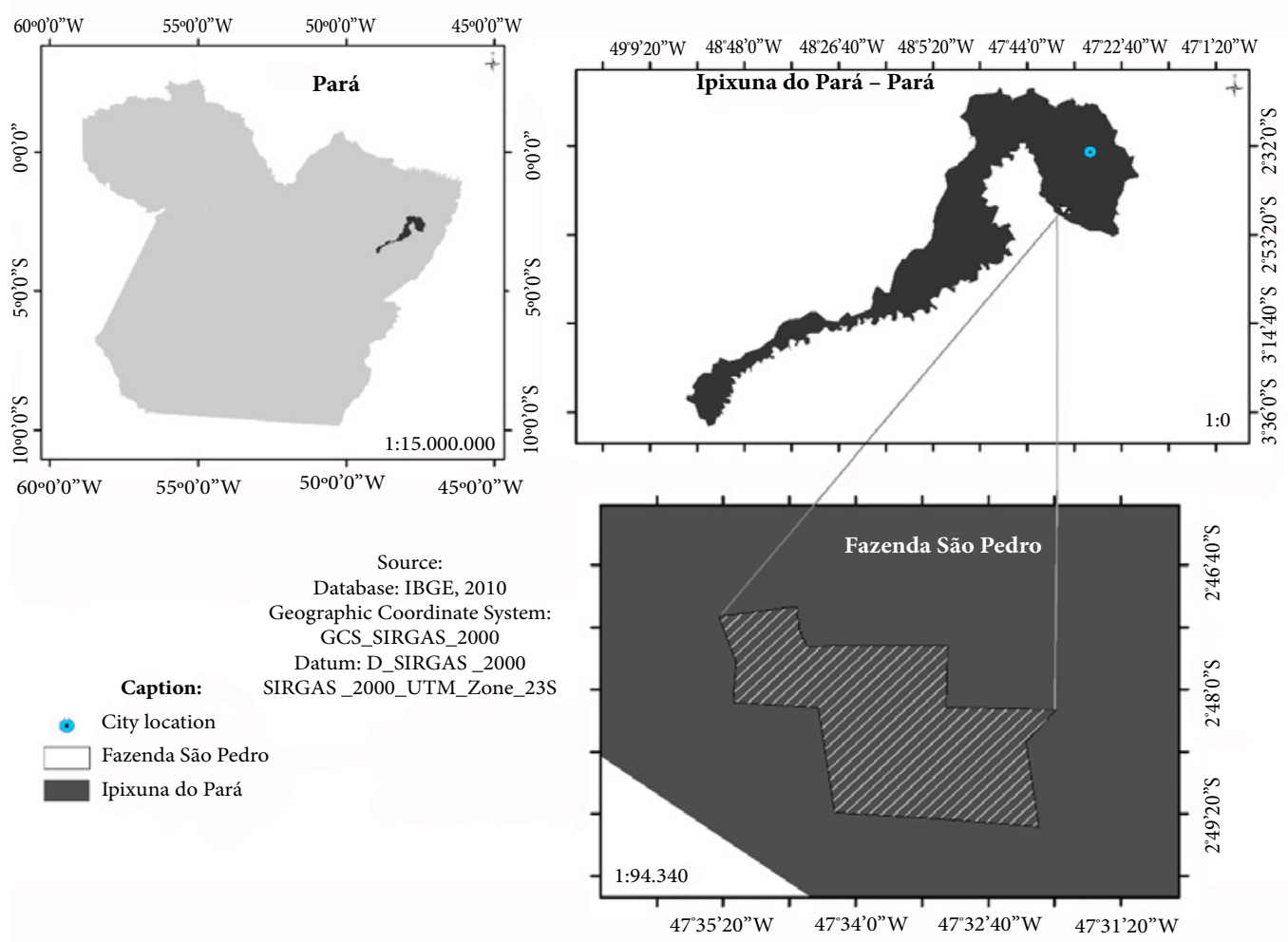

Figure 1. Location of the stands studied for the financial analysis of a Eucalyptus plantation in the municipality of Ipixina do Pará, Pará, Brazil. 


\subsection{Formation of the cash flow (CF)}

For the formation of the cash flow, the following costs were defined based on machine hour (cost of rent of machines per hour or cost of acquisition of machines diluted in services per hour and production), man hour (all labor costs specified by law, diluting the employees' wages to find the cost of man hour for each activity), machinery depreciation rate (machinery owned by the company), and inputs (all products used to control and maintain the plantation). All the activities and operations, as well as the costs involved in each of them regarding the planting and maintenance of the plantation, were identified and described. The costs described in Table 1 were considered for analysis purposes. Subsequently, a cost list for the operations of planting (beginning of Year 1) and maintenance of the plantation until harvesting age (Years 1-7) (Tables 1 and 2) was prepared considering the fixed and variable costs involved in the manual and mechanized forestry operations.

Table 1. Cost list for planting Eucalyptus with density of 1,428 trees per hectare in Fazenda São Pedro, municipality of Ipixuna do Pará, Pará, Brazil.

\begin{tabular}{|c|c|c|c|c|c|}
\hline A - MECHANIZED OPERATIONS & Unit & Qty/year & M/ha & UV & Year 0 (R\$/ha) \\
\hline Cutting and removal of vegetation & $\mathrm{Mch} / \mathrm{H}$ & 1 & 1 & 158.33 & 158.33 \\
\hline Opening of roads and firebreaks & $\mathrm{Mch} / \mathrm{H}$ & 1 & 1 & 158.33 & 158.33 \\
\hline Desiccation - total area & $\mathrm{Mch} / \mathrm{H}$ & 1 & 1 & 5.84 & 5.84 \\
\hline Grading and furrow opening with fertilization & $\mathrm{Mch} / \mathrm{H}$ & 1 & 1 & 61.48 & 61.48 \\
\hline Distribution of lime - on the line & $\mathrm{Mch} / \mathrm{H}$ & 1 & 1 & 9.16 & 9.16 \\
\hline Irrigation & $\mathrm{Mch} / \mathrm{H}$ & 10 & 1 & 9.91 & 99.10 \\
\hline Post-emergent herbicide & $\mathrm{Mch} / \mathrm{H}$ & 2 & 1 & 5.91 & 11.81 \\
\hline Fire prevention, brigading, and fighting & $\mathrm{Mch} / \mathrm{H}$ & 1 & 1 & 49.64 & 49.64 \\
\hline SUBTOTAL (A) & & & & & 553.69 \\
\hline B - MANUAL OPERATIONS & Unit & Qty/year & H/ha & $\mathrm{H} / \mathrm{V}$ & Year 0 (R\$/ha) \\
\hline Initial ant control & $\mathrm{M} / \mathrm{H}$ & 1 & 0.75 & 7.50 & 5.63 \\
\hline Pit marking for planting & $\mathrm{M} / \mathrm{H}$ & 1 & 1.04 & 37.50 & 39.00 \\
\hline Manual planting & $\mathrm{M} / \mathrm{H}$ & 1 & 1.04 & 37.50 & 39.00 \\
\hline Irrigation & $\mathrm{M} / \mathrm{H}$ & 10 & 0.67 & 14.72 & 98.62 \\
\hline Complementary ant control & $\mathrm{M} / \mathrm{H}$ & 2 & 0.75 & 7.56 & 11.34 \\
\hline Replanting & $\mathrm{M} / \mathrm{H}$ & 1 & 0.10 & 3.78 & 0.38 \\
\hline Manual clearing between plants & $\mathrm{M} / \mathrm{H}$ & 1 & 4 & 18.90 & 75.60 \\
\hline Topdressing & $\mathrm{M} / \mathrm{H}$ & 2 & 2 & 22.68 & 90.72 \\
\hline Fire prevention, brigading, and fighting & $\mathrm{M} / \mathrm{H}$ & 1 & 8 & 3.78 & 30.24 \\
\hline SUBTOTAL (B) & & & & & 390.53 \\
\hline C - INPUTS & Unit & Qty./year & Qty./ha & UV & Year 0 (R\$/ha) \\
\hline Seedlings & Individual & 1 & 1.428 & 0.35 & 499.80 \\
\hline Replanting (3\%) & Individual & 1 & 43 & 0.35 & 14.99 \\
\hline Lime & $\mathrm{Kg} / \mathrm{ha}$ & 1 & 800 & 0.29 & 228.00 \\
\hline Post-emergent herbicide & $\mathrm{Kg} / \mathrm{ha}$ & 3 & 2 & 23.5 & 141.00 \\
\hline Powder formicide & $\mathrm{Kg} / \mathrm{ha}$ & 1 & 2 & 9.5 & 19.00 \\
\hline Application of granulated bait & $\mathrm{Kg} / \mathrm{ha}$ & 2 & 2 & 14.3 & 57.20 \\
\hline N-P-K 10-22-15 (starter fertilization) & $\mathrm{Kg} / \mathrm{ha}$ & 1 & 450 & 1.32 & 594.00 \\
\hline N-P-K 14-00-20 (topdressing) & $\mathrm{Kg} / \mathrm{ha}$ & 2 & 167 & 1.28 & 427.52 \\
\hline SUBTOTAL (C) & & & & & $1,981.51 / \mathrm{ha}$ \\
\hline COST OF LAND (D) & $\mathrm{BRL}(\mathrm{R} \$)$ & & & & $1,370.00 / \mathrm{ha}$ \\
\hline TOTAL COST (R $\$ /$ ha/year) & & & & & $4,295.73 / \mathrm{ha}$ \\
\hline
\end{tabular}

Qty./year: quantity per year; Qty./ha: quantity per hectare; M/ha: machine per hectare; UV: unitary value; H/V: hour value; H/ha: hour per hectare; Mch/H: machine hour; M/H: man hour; $\mathrm{Kg} /$ ha: kilograms per hectare. 
Table 2. Estimate of maintenance costs from years 1 to 6.

\begin{tabular}{|c|c|c|c|c|c|c|c|c|c|c|}
\hline $\begin{array}{l}\text { A - MECHANIZED } \\
\text { OPERATIONS }\end{array}$ & Unit & M/ha & UV & Qty./year & $\begin{array}{l}\text { Year } 1 \\
\text { (R\$/ha) }\end{array}$ & $\begin{array}{c}\text { Year } 2 \\
\text { (R\$/ha) }\end{array}$ & $\begin{array}{l}\text { Year } 3 \\
\text { (R\$/ha) }\end{array}$ & $\begin{array}{c}\text { Year } 4 \\
\text { (R\$/ha) }\end{array}$ & $\begin{array}{l}\text { Year } 5 \\
\text { (R\$/ha) }\end{array}$ & $\begin{array}{c}\text { Year } 6 \\
\text { (R\$/ha) }\end{array}$ \\
\hline Post-emergent herbicide & $\mathrm{Mch} / \mathrm{H}$ & 1 & 5.91 & 2 & 11.81 & 11.81 & 11.81 & 11.81 & 11.81 & 11.81 \\
\hline Mowing & $\mathrm{Mch} / \mathrm{H}$ & 1 & 11.49 & 1 & - & 11.49 & 11.49 & 11.49 & 11.49 & 11.49 \\
\hline $\begin{array}{l}\text { Fire prevention, brigading, } \\
\text { and fighting }\end{array}$ & $\mathrm{Mch} / \mathrm{H}$ & 1 & 49.64 & 1 & 49.64 & 49.64 & 49.64 & 49.64 & 49.64 & 49.64 \\
\hline SUBTOTAL A & & & & & 61.45 & 72.94 & 72.94 & 72.94 & 72.94 & 72.94 \\
\hline B - MANUAL OPERATIONS & Unit & H/ha & $\mathbf{H} / \mathbf{V}$ & Qty./year & $\begin{array}{c}\text { Year } 1 \\
\text { (R\$/ha) }\end{array}$ & $\begin{array}{c}\text { Year } 2 \\
\text { (R\$/ha) }\end{array}$ & $\begin{array}{l}\text { Year } 3 \\
\text { (R\$/ha) }\end{array}$ & $\begin{array}{c}\text { Year } 4 \\
\text { (R\$/ha) }\end{array}$ & $\begin{array}{l}\text { Year } 5 \\
\text { (R\$/ha) }\end{array}$ & $\begin{array}{c}\text { Year } 6 \\
\text { (R\$/ha) }\end{array}$ \\
\hline Ant control & $\mathrm{M} / \mathrm{H}$ & 0.75 & 7.56 & 2 & 11.34 & 11.34 & 11.34 & 11.34 & 11.34 & 11.34 \\
\hline Manual clearing & $\mathrm{M} / \mathrm{H}$ & 4 & 18.90 & 1 & 75.60 & 75.60 & 75.60 & - & - & - \\
\hline Topdressing & $\mathrm{M} / \mathrm{H}$ & 2 & 22.68 & 1 & 45.36 & 45.36 & 45.36 & - & - & - \\
\hline $\begin{array}{l}\text { Fire prevention, brigading, } \\
\text { and fighting }\end{array}$ & $\mathrm{M} / \mathrm{H}$ & 8 & 3.78 & 1 & 30.24 & 30.24 & 30.24 & 30.24 & 30.24 & 30.24 \\
\hline SUBTOTAL B & & & & & 162.54 & 162.54 & 162.54 & 41.58 & 41.58 & 41.58 \\
\hline C - INPUTS & Unit & Qty/ha & UV & Qty./year & $\begin{array}{c}\text { Year } 1 \\
\text { (R\$/ha) }\end{array}$ & $\begin{array}{c}\text { Year } 2 \\
\text { (R\$/ha) }\end{array}$ & $\begin{array}{c}\text { Year } 3 \\
\text { (R\$/ha) }\end{array}$ & $\begin{array}{c}\text { Year } 4 \\
\text { (R\$/ha) }\end{array}$ & $\begin{array}{c}\text { Year } 5 \\
\text { (R\$/ha) }\end{array}$ & $\begin{array}{c}\text { Year } 6 \\
\text { (R\$/ha) }\end{array}$ \\
\hline Post-emergent herbicide & $\mathrm{Kg} / \mathrm{ha}$ & 2 & 23.50 & 2 & 94.00 & 94.00 & 94.00 & 94.00 & 94.00 & 94.00 \\
\hline Granulated bait & $\mathrm{Kg} / \mathrm{ha}$ & 2 & 14.30 & 2 & 57.20 & 57.20 & 57.20 & 57.20 & 57.20 & 57.20 \\
\hline N-P-K 14-00-20 (topdressing) & $\mathrm{Kg} / \mathrm{ha}$ & 167 & 1.28 & 1 & 213.76 & 213.76 & 213.76 & - & - & - \\
\hline SUBTOTAL C & & & & & $364.96 /$ ha & $364.96 / \mathrm{ha}$ & $364.96 / \mathrm{ha}$ & $151.20 / \mathrm{ha}$ & 151.20/ha & $151.20 / \mathrm{ha}$ \\
\hline $\begin{array}{l}\text { Annual interest on the value } \\
\text { of land }(10 \%)\end{array}$ & & & & & $137.00 / \mathrm{ha}$ & 137.00/ha & 137.00/ha & $137.00 /$ ha & $137.00 / \mathrm{ha}$ & 137.00/ha \\
\hline TOTAL COST (R\$/ha/year) & & & & & $725.95 / \mathrm{ha}$ & $737.44 / \mathrm{ha}$ & $737.44 / \mathrm{ha}$ & $402.72 / \mathrm{ha}$ & 402.72/ha & 402.72/ha \\
\hline
\end{tabular}

Qty./year: quantity per year; Qty/ha: quantity per hectare; M/ha: machine per hectare; UV: unitary value; H/V: hour value; H/ha: hour per hectare; Mch/H: machine hour; M/H: man hour; $\mathrm{Kg} /$ ha: kilograms per hectare.

In order to obtain the value of one hectare of bare land, the table of prices by microregion of the state of Pará was considered under the management of the Regional Superintendency Offices of INCRA (Silva \& Barreto, 2014). The annual interest rate assigned to the land was $10 \%$ a year, based on the SELIC rate for rural properties of 2017. An Excel spreadsheet was generated to verify the economic indicators, whereas information was collected on the average productivity and marketing prices of the forests in the region for the sensitivity analysis.

\subsection{Economic assessment criteria}

The following economic indicators (Equations 1, 2, 3,4 and 5) were used in the economic feasibility study (Rezende \& Oliveira, 2013).

\subsubsection{Net present value (NPV)}

$$
N P V=\sum_{j=0}^{n} R_{j}(1+i)-{ }^{-j}-\sum_{j=0}^{n} C_{j}(1+i)-^{-j}
$$

Where:

NPV: net present value;

C: cost at the end of period $j$;

$R$ : revenue at the end of period $j$;

i: discount rate;

n: number of project periods;

$\mathrm{j}$ : period in which costs and revenues occur $(j=0 \ldots n)$.

\subsubsection{Equivalent annual value (EAV)}

$\mathbf{E A V}=\frac{\mathrm{NPV} \times \mathrm{i}}{\left[1-(1+\mathrm{i})^{-\mathrm{n}}\right]}$

Where:

EAV: equivalent annual value;

NPV: net present value;

$\mathrm{n}$ : duration of project in years;

i: discount rate.

\subsubsection{Soil expectation value (SEV)}

$$
\mathbf{S E V}=\mathrm{NPV}_{\infty}+\mathrm{LV}
$$

Where:

SEV: soil expectation value;

$\mathrm{NPV} \infty$ : net present value of infinite cash flow;

LV: land value.

\subsubsection{Internal rate of return (IRR)}

$\mathbf{I R R}=\sum_{j=0}^{\mathrm{n}} \mathrm{R}_{\mathrm{j}}(1+\mathrm{IRR})^{-\mathrm{j}}-\sum_{\mathrm{j}=0}^{\mathrm{n}} \mathrm{C}_{\mathrm{j}}(1+\mathrm{IRR})^{-\mathrm{j}}=0$

Where:

IRR: internal rate of return;

$\mathrm{n}$ : rotation period in years;

$\mathrm{R}_{\mathrm{j}}$ : revenue at the end of period $\mathrm{j}$;

$C_{\text {; : }}$ cost at the end of period j;

i: discount rate. 


\subsubsection{Benefit-cost ratio (BCR)}

$$
\frac{\mathbf{B}}{\mathbf{C}} \mathbf{R}=\frac{\sum_{\mathrm{j}=0}^{\mathrm{n}} \mathrm{R}_{\mathrm{j}}(1+\mathrm{i})^{-\mathrm{j}}}{\sum_{\mathrm{j}=0}^{\mathrm{n}} \mathrm{C}_{\mathrm{j}}(1+\mathrm{i})^{-\mathrm{j}}}
$$

Where:

$\mathrm{n}$ : rotation period in years;

$\mathrm{j}$ : period in which costs and revenues occur $(j=0 \ldots n)$;

$\mathrm{R}_{\mathrm{j}}$ : revenue in the period $\mathrm{j}$;

$\mathrm{C}_{\mathrm{j}}$ : cost in period $\mathrm{j}$;

i: discount rate.

\subsection{Sensitivity analysis}

The feasibility study was subjected to sensitivity analysis based on the change in the total costs, revenues, and interest rate. The criteria for choosing the tested intervals were discussed in real fluctuations of the different timber marketing values in the region of the wood species studied, as well as the different interest rates provided by the banks and financial cooperatives in the region.

Given the several elements that amount to cost, variation in the total cost was considered. Another criterion adopted was the modification of revenue that can occur as a function of productivity in the different volumes produced in 1 ha of land for species in the region.

\section{RESULTS AND DISCUSSION}

\subsection{Productivity of the plantation}

The eucalyptus plantation analyzed responded positively to the type of clone used in the farm area. Based on the results of the inventory conducted by the company, a Mean Annual Increment (MAI) of $35 \mathrm{~m}^{3} /$ ha was reported, representing a production of $245 \mathrm{~m}^{3} / \mathrm{ha}$ at the end of the 7 -year period. In Brazil, the average productivity of eucalyptus plantations, reported by forest-based companies, was $35.7 \mathrm{~m}^{3} / \mathrm{ha} /$ year in 2016, leading the global ranking of forest productivity; however, eucalyptus productivity has increased by only $0.2 \%$ p.a. over the past five years (Ibá, 2017).

\subsection{Cash flow}

In this investment, costs with land acquisition and planting were $\mathrm{R} \$ 1,370.00 /$ ha and $\mathrm{R} \$ 4,295.73 / \mathrm{ha}$, respectively. The sum of the current costs of all the activities in both Tables showed an investment of approximately $\mathrm{R} \$ 7,704.73 /$ ha, which is considered average in long-term projects for pulp and paper production.

Virgens et al. (2015), studied a 7-year rotation clonal eucalyptus plantation located in the northern coast of Bahia and reported a planting cost of $\mathrm{R} \$ 3,840.01 /$ ha, equivalent to $58.06 \%$ of the total cost. Araújo et al. (2010) analyzed the economic viability of eucalyptus production for energy purposes in the municipality of Balsas, Maranhão, and observed that the planting phase was the most expensive of the project, reaching $67 \%$ of its total cost. Planting is considered the most onerous stage of a plantation due to the greater arrangement of activities and inputs needed. Nevertheless, maintenance activities (Years 1 to 7), despite their lower costs, are not insignificant, resulting in a cost of R\$ 3,408.99/ha. Costs with the control of weeds, ants, and fires were present in all years of the project, whereas costs with topdressing, weeding, and manual clearing occurred only up to Year 3 (Table 2). Corroborating these findings, a study conducted by Virgens et al., (2015) in a clonal eucalyptus plantation showed a cost with maintenance activities throughout the project of $\mathrm{R} \$ 2,773.40 /$ ha.

\subsection{Economic assessment criteria}

The following values were found for the economic indicators applied in this study after formation of the cash flow and updating of revenues and costs using a $10 \%$ discount rate per year: $\mathrm{NPV}=\mathrm{R} \$ 1,925.10 ; \mathrm{EAV}=\mathrm{R} \$ 395.43, \mathrm{SEV}=\mathrm{R} \$ 4,223.05$, $\mathrm{IRR}=16 \%$, and $\mathrm{BCR}=1.31$. Based on these results, the project can be considered economically viable.

Virgens et al., (2015) found values lower than those of the present study, namely, NPV $=\mathrm{R} \$ 1,279.01 / \mathrm{ha}, \mathrm{EAV}=\mathrm{R} \$ 152.00 / \mathrm{ha}$, $\mathrm{SEV}=\mathrm{R} \$ 1,937.20 / \mathrm{ha}$, IRR $=9.2 \%$, and $\mathrm{BCR}=1.20$; however, some numbers for economic analysis were different, such as MAI equals $33.08 \mathrm{~m}^{3} / \mathrm{ha} /$ year, marketing price of wood of $\mathrm{R} \$ 50.00 / \mathrm{m}^{3}$, and interest rate of $6 \%$ p.a.

Virgens et al. (2015) reported NPV $=\mathrm{R} \$ 1,399.24 /$ ha for a 5 -year period eucalyptus plantation, with a MAI of $35 \mathrm{~m}^{3} / \mathrm{ha}$, marketing price of wood of $\mathrm{R} \$ 40.00 / \mathrm{m}^{3}$, and interest rate of $10 \%$ p.a. These results provided Equivalent Periodic Value $(\mathrm{EPV})=\mathrm{R} \$ 359.29 / \mathrm{ha}, \mathrm{BCR}=1.44$, and $\mathrm{IRR}=18.54 \%$, evidencing values very close to those obtained in the present study. As the pruning cycle was different from that of this research, analysis of the EPV should be considered as a comparison parameter (Silva et al., 2005).

Silva \& Fontes (2005) verified the following economic indicator values: NPV = US\$ 506.66/ha, EAV = US\$ 104.07/ha, and $\mathrm{SEV}=\mathrm{US} \$ 1,440.71 / \mathrm{ha}$, corresponding to NPV $=\mathrm{R} \$ 1,666.91 / \mathrm{ha}$, $\mathrm{EAV}=\mathrm{R} \$ 342.39 / \mathrm{ha}$, and SEV $=\mathrm{R} \$ 4,739.93$ according to the exchange rate of USD $1.00=\mathrm{BRL} 3.29$ provided by the Central Bank of Brazil in 2017. The study period was similar to the one adopted in the present survey, with harvesting of trees at Year 7 and 10\% interest rate; however, productivity was $250 \mathrm{~m}^{3} / \mathrm{ha}$, differing from that of this research. 


\subsection{Sensitivity analysis}

Assuming that interest rate variation inversely affects project feasibility, sensitivity analysis becomes important, since it enables a holistic view of the project in different interest rate scenarios. Different NPV values were observed with assignments of different interest rates, as shown in Figure 2. As for the interest rate, sensitivity analysis coincides with identification of IRR, which is the rate that represents the interface regarding the viability of the project.



Figure 2. Sensitivity analysis for the net present value (NPV) with different interest rates in a Eucalyptus plantation in the municipality of Ipixuna do Pará, Pará, Brazil.
Economic and sensitivity analyses have proved to be planning tools capable of guiding decision-making regarding investment in Eucalyptus reforestation projects (Virgens et al., 2015) in which cost, interest, MAI, and marketing price of wood are variables that affect the economic viability of an enterprise. The exception is based on the absence of relation between interest and IRR. Table 3 shows the influence of variables on the values of the feasibility indicators.

According to Rezende et al. (2006), the net profitability of forests depends not only on interest rate, but also on the type of clone used in the region, timber price, production purpose, MAI etc.

Simulations conducted with the highest interest rate (15\%), the lowest $\operatorname{MAI}\left(35 \mathrm{~m}^{3} / \mathrm{ha} /\right.$ year), and the three lowest marketing values of wood $\left(\mathrm{R} \$ 50.00 / \mathrm{m}^{3}, 55.00 / \mathrm{m}^{3}\right.$, and $60.00 / \mathrm{m}^{3}$ ) indicated that the project was not viable, and the same occurred with the lowest timber value with a MAI of $40 \mathrm{~m}^{3} / \mathrm{ha} /$ year. In advance, it is possible to state that, for a more profitable economic return, genetic materials better adapted to the climatic conditions of the region can be used to generate volumetric yields higher than the current $245 \mathrm{~m}^{3} / \mathrm{ha}$. Therefore, it is essential to incentive new studies addressing the increase of productivity resulting from the application of management and forestry techniques for the planting of eucalyptus in the region.

Table 3. Sensitivity analysis with different interest rates, increment, and marketing value in Eucalyptus plantation with density of 1428 trees per hectare in Ipixuna do Pará, Pará, Brazil.

\begin{tabular}{|c|c|c|c|c|c|c|}
\hline $\begin{array}{c}\text { Interest rate } \\
(\%)\end{array}$ & MAI (m³/ha.year) & Value of $\operatorname{wood}\left(\mathrm{m}^{3} / \mathrm{R} \$\right)$ & NPV (R\$) & EAV (R\$) & $\begin{array}{l}\text { BCR } \\
(\mathrm{R} \$)\end{array}$ & $\begin{array}{l}\text { IRR } \\
(\%)\end{array}$ \\
\hline 5 & 35 & 50.00 & $1,810.22$ & 312.84 & 1.01 & 10 \\
\hline 5 & 35 & 55.00 & $2,680.81$ & 463.30 & 1.11 & 12 \\
\hline 5 & 35 & 60.00 & $3,551.39$ & 613.75 & 1.21 & 14 \\
\hline 5 & 35 & 65.00 & $4,421.98$ & 764.21 & 1.31 & 16 \\
\hline 5 & 35 & 70.00 & $5,292.56$ & 914.66 & 1.41 & 18 \\
\hline 5 & 40 & 50.00 & $3,053.92$ & 527.78 & 1.15 & 13 \\
\hline 5 & 40 & 55.00 & $4,048.87$ & 699.72 & 1.27 & 15 \\
\hline 5 & 40 & 60.00 & $5,043.82$ & 871.67 & 1.38 & 17 \\
\hline 5 & 40 & 65.00 & $6,038.78$ & $1,043.62$ & 1.50 & 19 \\
\hline 5 & 40 & 70.00 & $7,033.73$ & $1,215.57$ & 1.61 & 21 \\
\hline 5 & 45 & 50.00 & $4,297.61$ & 742.71 & 1.29 & 16 \\
\hline 5 & 45 & 55.00 & $5,416.93$ & 936.15 & 1.42 & 18 \\
\hline 5 & 45 & 60.00 & $6,536.25$ & $1,129.59$ & 1.55 & 20 \\
\hline 5 & 45 & 65.00 & $7,655.58$ & $1,323.04$ & 1.68 & 22 \\
\hline 5 & 45 & 70.00 & $8,774.90$ & $1,516.48$ & 1.81 & 24 \\
\hline 10 & 35 & 50.00 & 39.24 & 8.06 & 1.01 & 10 \\
\hline 10 & 35 & 55.00 & 667.86 & 137.18 & 1.11 & 12 \\
\hline
\end{tabular}


Table 3. Continued...

\begin{tabular}{|c|c|c|c|c|c|c|}
\hline $\begin{array}{c}\text { Interest rate } \\
(\%)\end{array}$ & MAI (m³/ha.year) & Value of wood $\left(\mathrm{m}^{3} / \mathrm{R} \$\right)$ & NPV (R\$) & EAV (R\$) & $\begin{array}{l}\text { BCR } \\
(\mathrm{R} \$)\end{array}$ & $\begin{array}{l}\text { IRR } \\
(\%)\end{array}$ \\
\hline 10 & 35 & 60.00 & $1,296.48$ & 266.30 & 1.21 & 14 \\
\hline 10 & 35 & 65.00 & $1,925.10$ & 395.43 & 1.31 & 16 \\
\hline 10 & 35 & 70.00 & $2,553.72$ & 524.55 & 1.41 & 18 \\
\hline 10 & 40 & 50.00 & 937.27 & 192.52 & 1.15 & 13 \\
\hline 10 & 40 & 55.00 & $1,655.69$ & 340.09 & 1.27 & 15 \\
\hline 10 & 40 & 60.00 & $2,374.11$ & 487.66 & 1.38 & 17 \\
\hline 10 & 40 & 65.00 & $3,092.53$ & 635.22 & 1.50 & 19 \\
\hline 10 & 40 & 70.00 & $3,810.95$ & 782.79 & 1.61 & 21 \\
\hline 10 & 45 & 50.00 & $1,835.29$ & 376.98 & 1.29 & 16 \\
\hline 10 & 45 & 55.00 & $2,643.52$ & 542.99 & 1.42 & 18 \\
\hline 10 & 45 & 60.00 & $3,451.74$ & 709.01 & 1.55 & 20 \\
\hline 10 & 45 & 65.00 & $4,259.97$ & 875.02 & 1.68 & 22 \\
\hline 10 & 45 & 70.00 & $5,068.19$ & $1,041.03$ & 1.81 & 24 \\
\hline 15 & 35 & 50.00 & $-1,111.36$ & -228.28 & 1.01 & 10 \\
\hline 15 & 35 & 55.00 & -650.83 & -133.68 & 1.11 & 12 \\
\hline 15 & 35 & 60.00 & -190.31 & -45.74 & 1.21 & 14 \\
\hline 15 & 35 & 65.00 & 270.21 & 64.95 & 1.31 & 16 \\
\hline 15 & 35 & 70.00 & 730.74 & 175.64 & 1.41 & 18 \\
\hline 15 & 40 & 50.00 & -453.47 & -109.00 & 1.15 & 13 \\
\hline 15 & 40 & 55.00 & 72.85 & 17.51 & 1.27 & 15 \\
\hline 15 & 40 & 60.00 & 599.16 & 144.01 & 1.38 & 17 \\
\hline 15 & 40 & 65.00 & $1,125.47$ & 270.52 & 1.50 & 19 \\
\hline 15 & 40 & 70.00 & $1,651.70$ & 397.02 & 1.61 & 21 \\
\hline 15 & 45 & 50.00 & 204.42 & 49.14 & 1.29 & 16 \\
\hline 15 & 45 & 55.00 & 796.52 & 191.45 & 1.42 & 18 \\
\hline 15 & 45 & 60.00 & $1,388.63$ & 333.77 & 1.55 & 20 \\
\hline 15 & 45 & 65.00 & $1,980.73$ & 476.09 & 1.68 & 22 \\
\hline 15 & 45 & 70.00 & $2,572.83$ & 618.41 & 1.81 & 24 \\
\hline
\end{tabular}

MAI: mean annual increment; NPV: net present value; EAV: equivalent annual value; IRR: internal rate of return; BCR: benefit-cost ratio.

\section{CONCLUSION}

As it was proposed, the cash flow of the project presented significant expenses with the purchase of inputs. For the company, the implementation of the Eucalyptus plantation was viable considering the analyzed economic indicators and presents profitability to the project.

Sensitivity analysis provided an economic view for the production and commercialization of raw material for the pulp industry with Eucalyptus plantation. However, further research and incentives are needed for the economic assessment of forest stands in the mesoregion of southeastern Pará, since there are large areas in this region favorable to the implementation of planted forest projects.

\section{ACKNOWLEDGEMENTS}

We would like to thank TFA, company that provided the study area and supported the development of the study.

\section{SUBMISSION STATUS}

Received: 15 Mar. 2018

Accepted: 28 Sept. 2018

Associate editor: Vanessa Maria Basso

(D) 0000-0003-3141-2262

\section{CORRESPONDENCE TO}

Janderson de Oliveira Silva

Rua Caravelas, 235, Promissão 2, CEP 68628-360, Paragominas, PA, Brasil e-mail: janderson_o.silva@hotmail.com 


\section{REFERENCES}

Araújo ARA, Fonseca FST, Hendges TL. Análise de viabilidade econômica da produção de eucalipto na cidade de Balsas - MA para a geração de energia. Revista Científica da Faculdade de Balsas 2010; 1(1): 1-21.

Carvalho RMMA, Soares TS, Valverde SR. Caracterização do setor florestal: uma abordagem comparativa com outros setores da economia. Ciência Florestal 2005; 15(1): 105-118. $10.5902 / 198050981828$

Climate-Data.org. Clima: Ipixuna do Pará [Internet]. 2016 May 22 [cited 2017 Mar 15]. Available from: https://bit.ly/2JONIYV

Indústria Brasileira de Árvores - Ibá. Relatório Ibá 2015. Brasília: Ibá; 2015.

Indústria Brasileira de Árvores - Ibá. Relatório Ibá 2016. Brasília: Ibá; 2016.

Indústria Brasileira de Árvores - Ibá. Relatório Ibá 2017. Brasília: Ibá; 2017.

Rezende JLP, Padua CTJ, Oliveira AD, Scolforo JRS. Análise econômica de fomento florestal com eucalipto no estado de Minas Gerais. Cerne 2006; 2(3): 221-231.
Rezende JLP, Oliveira AD. Análise econômica e social de projetos florestais. 3rd ed. Viçosa: Editora UFV; 2013.

Sant'Anna AG, Leonel MS. Projeto de viabilidade: a importância da avaliação de projetos florestais para produtores rurais. Unimontes Científica 2009; 11(1-2): 1-7.

Santana AC. Elementos de economia, agronegócio e desenvolvimento local. Belém: GTZ; TUD; UFRA; 2005.

Silva D, Barreto P. O potencial do Imposto Territorial Rural contra o desmatamento especulativo na Amazônia. Belém: IMAZON; 2014.

Silva ML, Fontes AA. Discussão sobre os critérios de avaliação econômica: valor presente líquido (VPL), valor anual equivalente (VAE) e valor esperado da terra (VET). Revista Árvore 2005; 29(6): 931-936. 10.1590/S0100-67622005000600012

Silva ML, Jacovine LAG, Valverde SR. Economia florestal. 2nd ed. Viçosa: Editora UFV; 2005.

Virgens AP, Freitas LC, Leite AMP. Análise econômica e de sensibilidade em um povoamento implantado no sudoeste da Bahia. Floresta e Ambiente 2003; 23(2): 211-219. 10.1590/2179-8087.104914

Virgens AP, Freitas LC, Luz DS, Moreira ACD. Análise econômica e de sensibilidade em projetos de reflorestamentos no estado da Bahia. Enciclopédia Biosfera 2015; 21(1): 120-127. 